\title{
ASSESSMENT OF AGRO-MARKETERS' PATRONAGE OF PRIVATE COMMERCIAL COLD ROOMS IN ABAKALIKI URBAN AREA OF EBONYI STATE, NIGERIA
}

S. U. NWIBO AND N. E. ODO

(Received 17, February 2009; Revision Accepted 1, June 2009)

\begin{abstract}
The study assessed the agro-marketers' patronage of private commercial coldrooms in Abakaliki Urban area of Ebonyi State. Purposive sampling technique was employed in selecting 120 respondents (30 cold room operators and 90 agro-marketers) used for the study. Data were collected from primary source using structured questionnaires. Descriptive statistics such as mean, tables, percentages, difference in means were employed to analyse objectives $i$ and ii, objective iii was analysed using ordinary least squares regression analysis; whereas, objective iv was analysed using gross margin analysis; whereas, and objective $v$ was analysed using mean score (obtained from a 4-point likert rating scale of 2.5 weighted mean). The results obtained have shown that majority of the agro-marketers were females $(80 \%)$ as most of the males were involved in the operation and management of coldrooms. It further, revealed that $66 \%\left(R^{2}=0.659\right)$ of the total variation on the level of patronage were explained by the combined effects of the explanatory variables, as the coefficients of educational and income status of the agro-marketers were both positive and significant at $5 \%$ level. The F-test of the analysis showed that the socio-economic characteristics of the respondents have a significant effect on the patronage of private commercial coldrooms in the study area. The analysis revealed further a higher gross marketing margin for unrefrigerated agro-products than refrigerated agroproducts (18.3\% and $16.5 \%$ gross margins respectively). Factors like cost of refrigerating agro-products (3.3), use of local refrigerating facilities (2.7), inadequate power supply (2.6), and lack of market information (2.5) were identified as the major constraints to effective patronage of private commercial coldrooms in Abakaliki urban. From the findings, the study recommended that the public power supply should be enhanced to ensure constant power supply; and that agro-marketers should be sensitized towards coldroom patronage and need for market information.
\end{abstract}

KEY WORDS: agro-marketers, patronage, coldroom, refrigerating, agro-products.

\section{INTRODUCTION}

Agricultural product faces deterioration due to inadequate storage facilities (Potter and Hotchkiss, 2001). Most of the agricultural products that deteriorate rapidly are the commodities which are used daily. Such commodities are fresh milk, meat, fish, fruits and vegetables, and even cooked food. However, in order to improve the shelf-life of such foods, it is important to understand the cause of food spoilage since preservation can be objectively pursued. Storage service is imperative as items produced are not just bought or purchased immediately but, are kept in a facility that can preserve and hold such items in anticipation of sales (Okeke, 2003).

Storage is concerned with the performance of the activities that help to keep inventories in custody until they are needed (Olakunle, 2005). However, we do not talk of preservation without the storage facilities such as containers, chambers or rooms specially designed to preserve the required food or product. Efficient product storage ensures that products are kept in convenient and good condition till when they reach the final consumers.

On commercial basis, products are stored in commercial or public coldrooms. A public coldroom is a cooling and storage facility established by an individual, government or its agency to offer storage and other storage services to interested persons or organisations for a fee. Highlighting its importance, Fisher (2008) opined that, it provides suitable environment for the storage of stocks as well as preservation of products or items against spoilage and damage due to harsh weather. He further opined that marketers sometimes fear patronising coldroom on the ground that it will increase unit cost, reduce product demand and thus, leading to reduced net gain. But, Cecil and Woodroof (2002) asserted that since agricultural produce can be held in good condition for many years under certain condition, it is important to establish the condition and storage periods which afford the optimum balance between costs of storage and of changes in quality of stored products.

It is a fact that most of agricultural produce are perishable and the bulk of it comes from the rural area with most of the farmers being subsistent hence, making output insufficient to meet the requirement of the teaming population.

However, despite the perishable and risky nature of most agricultural products (Okaka, 2001), many marketers of the products abound. Based on the abundance of the agro-marketers and the multiplicity of coldrooms in the area, it seems that the agro-marketers are not effectively utilising the services of the coldrooms as wastes and gluts occur at the markets on daily basis. Based on the prevailing situation, the study seeks to find possible panaceas to the following questions: what are the socioeconomic characteristics of the agromarketers? Do the socioeconomic characteristics of the markers affect their patronage of the coldroom? Are the 
marketers aware that commercial coldrooms exist in the area? How accessible are the coldrooms to the marketers? What factors influence/hinder the marketers from patronising private commercial coldrooms?

The broad objective of the study was to determine the agro-marketers' patronage of private commercial coldrooms in Abakaliki urban area and specifically, to: describe the socioeconomic characteristics of the agro-marketers; categorise and analyse the types of products that are marketed by the agro-marketers; determine the effect of socioeconomic characteristics of agro-marketers on the patronage of commercial coldrooms; ascertain the difference in revenue obtained from marketing refrigerated and unrefrigerated agro products; and to analyse the constraints to effective patronage of private commercial coldrooms by agro-marketers.

Based on the objectives, the following hypotheses were put forward for testing:

$\mathrm{H}_{\mathrm{O}}$ : the socioeconomic characteristics of the agromarketers have no significant effect on the patronage of private commercial coldrooms in Abakaliki urban.

$\mathrm{H}_{\mathrm{O}}$ : there is no significant difference between the revenue obtained from marketing refrigerated and non refrigerated agro-products.

\section{METHODOLOGY}

The study area is Abakaliki urban area of Ebonyi State. The area is made up of two Local Government Areas of Abakaliki and Ebonyi respectively. It has a population of 151,723 people. The people's occupations are mainly farming and trading. There are thirty (30) privately owned commercial coldrooms located at the various parts of the area.

Purposive sampling technique was employed in the section of thirty (30) coldroom operators and ninety (90) agro-marketers used for the study.

Data were collected using primary sources (structured questionnaires). Data collected were analysed using both descriptive and inferential statistics. Descriptive statistics such as table, percentages, means, etc were used to analyse objectives i and ii, objective iii was analysed using ordinary least squares regression technique, objective iv was analysed using gross margin analysis, while objective $v$ was analysed using a mean score obtained on 4-point likert scale.

Hypotheses $\left(\mathrm{H}_{\mathrm{O}_{1}}\right)$ and $\left(\mathrm{H}_{\mathrm{O} 2}\right)$ were tested using $\mathrm{F}$-test and Z-test (test of difference in mean) respectively at $5 \%$.

\section{Variable specification}

The regression model was specified as:

$Y=f\left(x_{1}, x_{2}, X_{3}, x_{4}, x_{5}, x_{6}\right) \ldots$ implicit form

$Y=a_{o}+a_{1} X_{1}+a_{2} X_{2}+a_{3} X_{3}+a_{4} X_{4}+a_{5} X_{5}+a_{6} X_{6}+e t \ldots$ explicit stochastic form

Where: visited)

$\mathrm{Y}=$ level of patronage (average number of times

$a_{0}=$ constant

$a_{1}-a_{6}=$ coefficients $x_{1} \ldots x_{6}=$ socioeconomic characteristics of the agro-marketers

$x_{1}=$ age

$x_{2}=$ gender

$x_{3}=$ marital level

$x_{4}=$ educational status

$x_{5}=$ years of experience

$x_{6}=$ income status

et $=$ error term

The model for testing $\mathrm{H}_{\mathrm{O} 2}$ is stated as:

$Z=\frac{\bar{X}_{1}-\bar{X}_{2}}{\sqrt{\frac{\sigma_{1}^{2}}{n_{1}}+\frac{\sigma_{2}^{2}}{n_{2}}}}$ at 0.05 level of significance

Where; $\quad Z=$ critical value or $Z$ calculated

$\bar{X}_{1}=$ mean value of revenue from refrigerated agro products

$\bar{X}_{2}=$ mean value of revenue from

unrefrigerated agro products

$\sigma_{1}=$ standard deviation of revenue from refrigerated agro products

$\sigma_{2}=$ standard deviation of revenue from unrefrigerated agro products

$n_{1}=$ total number of respondents that sell refrigerated agro products

$n_{2}=$ total number of respondents that sell unrefrigerated agro products

\section{RESULTS AND DISCUSSION}

\section{Socioeconomic characteristics}

From the analyses in table 1 , it was observed that majority of the agro-marketers are females (80\%) who are within the age brackets of $21-60$ years. It further revealed that most of the marketers are partly educated as evident from the $25.6 \%$ and $34.4 \%$ of them holding First School Leaving Certificate (FSLC) and Senior School Certificate Examination (SSCE) respectively. Meanwhile, it has been observed that the operators of the coldrooms are highly educated (80\%). This finding justifies the work of Forest (2007), who disclosed that the business of coldroom need a specialised knowledge as to know when to increase or decrease temperature, service the engine, and to effectively see to the working of the enterprise.

\section{Types of agro products marketed}

The type of agro products marketed by the agro marketers may take different forms but, their provision depends on the needs and wants of the customers and the ability and willingness of the organisation to provide them at reasonable prices (Lancaster, 2002). From the result presented in table 2 , it was observed that greater percentage of the respondents market fishes $(39.2 \%)$ and meat $(35 \%)$. Meanwhile, most of the meat marketers sell beef and chevon (goat meat). The low rate of chicken marketing can be attributed to the ban on the importation of frozen foods by the Federal Government of Nigeria. 
Effect of socioeconomic characteristics on the coldroom patronage

From the regression analysis presented in table 3 , the following results were obtained:

F-ratio $=36.334, F-t a b=36.338$, standard error of the estimate $=0.5615$

The regression equation of the coefficient estimate is represented as:

$\mathrm{Y}=0.338+0.006126 \mathrm{x}_{1}+0.04152 \mathrm{x}_{2}+0.07196 \mathrm{x}_{3}+$ $0.01386 x_{4}+0.009707 x_{5}+0.000009102 x_{6}+e t$
$(0.248) \quad(0.006)$
(0.009) (0.000)*
$(0.157) \quad(0.073) \quad(0.012)^{*}$

The value in brackets are the standard errors of parameters.

The regression results as indicated by the coefficient of multiple determination $\left(R^{2}=0.659\right)$ show that the combined effects of the explanatory variables explained $66 \%$ of the total variation on the level of patronage of the private commercial coldrooms by the agro-marketers. The remaining $34 \%$ variation could be as a result of non inclusion of some important explanatory variables in the model.

The coefficients of educational status and income status were positive and significant at $5 \%$ level. This implies that both education status and income status have a direct relation with level of patronage of coldroom by agro-marketers. Other independent variables were positively signed but not significant at $5 \%$ level. This shows an inverse relationship with the patronage of coldroom by the agro-marketers.

The test of goodness of fit of the regression line shows that F-calculated was $36.4 @$ a probability of 5\% and F-tabulated was 36.338. Thus, F-cal > F-tab leading to the rejection of the null hypothesis. Hence, the socioeconomic characteristics of the agro-marketers have a significant effect on the level of private commercial coldrooms in Abakaliki urban area.

\section{Gross margin analysis}

From the gross margin obtained, it was observed that there was a higher gross marketing margin for unrefrigerated agro-products than refrigerated agro-products. This was justified by the gross margin (GM) and profit of N199250 (16.5\%) and N102500 respectively for refrigerated products and N224800 (18.3\%) and N150421 respectively for unrefrigerated agro-products. Hence, the marketing of unrefrigerated agro-products is more viable than marketing of refrigerated products, though the result of test of hypothesis at $5 \%$ level revealed that there is no significant difference between the marketing of the two products. In justification of the finding, Scarborough and Kydd (1997), inferred that in assessing the marketing performance using gross margin, $10 \%$ gross marketing margin is acceptable for perishable goods.

\section{Constraint to effective patronage of private} commercial coldrooms by agro-marketers

The study shows that agro-marketers are faced with some problems that constrain them from patronising coldrooms. The constraints were scaled on a 4-point likert scale with a weighted mean of 2.5. From the result presented on table 4 , it revealed that the major constraints are inadequate power supply (2.6), high cost of refrigerating agro-products (3.3), lack of marketing information (2.5), the use of local refrigerating facilities as alternative to private coldrooms (2.7), and consumer's preference to unrefrigerated agro-products than refrigerated agro-products (2.9).

The implication of the finding is that, it will be relatively difficult for most marketers to patronise private commercial coldroom as it has been revealed that the cost of refrigerating agro-products increases the unit cost of products, hence making the product less competitive than unrefrigerated ones whose prices are lower as consumers prefer unrefrigerated agro-products (meat, vegetables, and fishes) to refrigerated ones.

\section{SUMMARY}

The study identified the major marketers of agro-products as females (80\%) within the age brackets of 21-60 years. It equally revealed that most of the marketers were not well educated as against the operators that were well educated. It was also observed that the educational status and the income level of the marketers have significant effects on the level of patronage of private commercial coldrooms. Meanwhile, the marketers of fishes and meat (beef and chevon) have been identified as the major patronisers of private commercial coldrooms in Abakaliki urban area. The study further revealed that marketing of unrefrigerated agro-products was more viable than the marketing of refrigerated agro-products. This was justified by the $16.5 \%$ and $18.3 \%$ gross margins respectively.

Factors such as inadequate power supply, lack of marketing information, cost of refrigerating agroproducts, and use of local refrigerating facilities have been identified to have major influence in constraining marketers from patronising private commercial coldrooms.

\section{CONCLUSION}

Despite the numerous benefits of patronising private commercial coldrooms by agro-marketers, it has been observed that there was a low level of patronage of services coldroom operators by the agro-marketers in the area.

\section{RECOMMENDATIONS}

Based on the findings, the following recommendations are made:

The public power supply should be enhanced to ensure constant power supply to consumers;

Agro-marketers should be fully sensitised on the importance of patronising private commercial coldrooms so as to help in ensuring all year round supply of products; Local governments should establish commercial coldrooms in their locality so as to help in reducing the price of storing products;

Both coldroom operators and agromarketers should always seek for market information on product availability and storage. 
Table 1: Socioeconomic characteristics of the respondents

\begin{tabular}{llll} 
Socioeconomic & Description & operators(\%) & marketers(\%) \\
\hline Gender & male & $19(63.3)$ & $18(20.0)$ \\
Age & Female & $11(36.7)$ & $72(80.0)$ \\
& $<20$ & $0(0.0)$ & $15(16.7)$ \\
& $21-40$ & $6(20.0)$ & $23(25.6)$ \\
& $41-60$ & $20(66.7)$ & $32(35.5)$ \\
Marital status & $>60$ & $4(13.3)$ & $20(22.2)$ \\
& single & $0(0.0)$ & $28(31.1)$ \\
& Married & $30(100.0)$ & $51(56.7)$ \\
Experience & Divorced & $0(0.0)$ & $0(0.0)$ \\
& Widowed & $0(0.0)$ & $11(12.2)$ \\
& $<4$ years & $0(0.0)$ & $2(2.2)$ \\
& $5-7$ “ & $4(13.3)$ & $18(20.0)$ \\
& $8-10$ “ & $8(26.7)$ & $22(24.4)$ \\
Income status & $11-13$ “ & $16(53.3)$ & $41(45.6)$ \\
& $>14$ years & $2(6.7)$ & $7(7.8)$ \\
& $<$ N50,000 & $0(0.0)$ & $0(0.0)$ \\
& N51,000-100,000 & $3(10.0)$ & $10(11.1)$ \\
& N101,000-150,000 & $6(20.0)$ & $30(33.3)$ \\
& N151,000-200,000 & $13(43.3)$ & $32(35.6)$ \\
& $>201,000$ & $8(26.7)$ & $28(31.1)$
\end{tabular}

Source: field survey, 2008.

Table 2: percentage distribution of the agro-marketers based on the type of product(s) marketed

\begin{tabular}{lll}
\hline Agro-product & respondents & percentage \\
\hline Fish & 47 & 39. \\
Meat & 42 & 35.0 \\
Fruits & 11 & 9.1 \\
Vegetables & 20 & 16.6 \\
Total & $\mathbf{1 2 0}$ & $\mathbf{1 0 0}$ \\
\hline
\end{tabular}

Source: Field survey, 2008.

Table 3: Result of regression analysis on the effect of socioeconomic characteristics on the coldroom patronage

\begin{tabular}{lllll}
\hline Variables & $\begin{array}{l}\text { variable } \\
\text { names }\end{array}$ & $\begin{array}{l}\text { regression } \\
\text { coefficients }\end{array}$ & $\begin{array}{l}\text { standard } \\
\text { error }\end{array}$ & t-value \\
\hline Constant & & 0.338 & 0.248 & 1.366 \\
$\mathrm{x}_{1}$ & age & 0.006126 & 0.006 & 1.088 \\
$\mathrm{x}_{2}$ & sex & 0.04152 & 0.157 & 0.265 \\
$\mathrm{x}_{3}$ & marital status & 0.07196 & 0.073 & 0.988 \\
$\mathrm{x}_{4}$ & educational status & 0.01386 & 0.012 & $1.125^{*}$ \\
$\mathrm{x}_{5}$ & family size & 0.009707 & 0.009 & 1.028 \\
$\mathrm{x}_{6}{ }^{*}$ significant @ & annual income & 0.000009102 & 0.000 & $10.815^{*}$ \\
$\mathrm{R}=0.812$ & & & \\
$\mathrm{R}^{2}=0.659$ & & & &
\end{tabular}

Table 4: Constraints to effective patronage of commercial by agro-marketers

\begin{tabular}{lcl}
\hline Constraints & $\bar{X} s$ & Decision \\
\hline Inadequate power supply & 2.6 & accepted \\
Inadequate space to store products & 1.8 & rejected \\
Lack of market information & 2.5 & accepted \\
Costly nature of refrigerated products & 2.1 & rejected \\
Distance of the coldroom from market & 1.8 & rejected \\
Cost of refrigerating agro-products & 3.3 & accepted \\
Low demand for refrigerated products & 1.7 & rejected \\
Lack of advertisement & 1.6 & rejected \\
Poor attitude of agro-marketers & 2.0 & rejected \\
Insufficient private commercial & & \\
coldrooms & 1.9 & rejected \\
Use of local refrigerating facilities & 2.7 & accepted \\
Consumers preference of unrefrigerated & \\
products & 2.9 & accepted \\
\hline \multicolumn{2}{l}{ Source: field survey 2008} &
\end{tabular}




\section{REFERENCE}

Cecil, S. R. and Woodroot, J. G., 2002. Long-term storage of military rations. Agricultural experiment technology journal. (2)1: 16- 20.

Fisher, R., 2008. Food preservation. Journal of food technology. Robert Publications, UK. 2(3): 68 72.

Forest, R. J., 2007. From farm to freezer. Indian Journal of Food Technology. 1(2):44 - 49.

Lancaster, G., 2000. Physical distribution management. Lecture monograph. P.50.
Okaka, J. C., 2001. Food composition, spoilage, shelflife extension. OCJANCO academic publishers, Enugu. P.107.

Okeke, C. I., 2003. Principle of marketing. New generation books, Enugu. P.10.

Olakunle, K. O., 2005. Marketing logistics management. Providence press, Enugu. Pp. $83-84$.

Potter, N. N. and Hotchkiss, J. N., 1995. Food science. $5^{\text {th }}$ edition. Chapman and Hall, New York. P.163

Scarborough, V. and Kydd, J., 1997. Economic analysis of agricultural markets. A manual. Chathan, UK. Vol. 5 